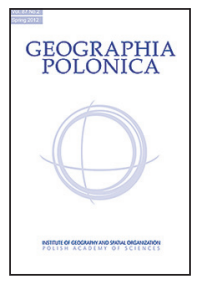

\title{
SOIL WATER STORAGE IN POLAND OVER THE YEARS 2000-2015 IN RESPONSE TO PRECIPITATION VARIABILITY AS RETRIEVED FROM GLDAS NOAH SIMULATIONS
}

\section{Urszula Somorowska}

Faculty of Geography and Regional Studies

University of Warsaw

Krakowskie Przedmieście 30, 00-927 Warsaw: Poland

e-mail: usomorow@uw.edu.pl

\begin{abstract}
This study assesses the soil water storage in Poland over the years 2000-2015. Soil water storage (SWS) data were acquired from the GLDAS Noah model simulations. The specific objectives were to provide a quantitative assessment of the SWS in the soil layer of $0-50 \mathrm{~cm}$ depth to detect extreme stages of SWS, and to provide an insight into the effects of precipitation deficit or surplus on the stage of SWS. Extremely low SWS was detected to occur in August 2003, July 2006, and September 2015. Contrasting high SWS stages appeared in May and June 2010, caused by excessive precipitation.
\end{abstract}

\section{Key words}

soil water storage $\bullet$ variability $\bullet$ GLDAS Noah $\bullet$ Poland

\section{Introduction}

Soil water storage(SWS) plays a key role in the hydrological cycle through its impact on the partitioning of precipitation into infiltration and runoff at the surface-subsurface interface. It also controls the evaporation from the soil and transpiration from plants. In effect, the SWS influences the formation of floods and droughts. The effects of such extreme hydrological events cause an excess or shortage of water in the natural environment (Jokiel 2008; Kędziora et al. 2014; Romanowicz et al. 2014). In the face of these threats, the recognition of SWS is an important element of the assessment of water resources. In temperate climate, the soil moisture cycle comprises the recharge of SWS during rainy events and its depletion by evapotranspiration during rainless periods. The period in which SWS increases is named the 'accumulating season' and the period when soil water storage falls - the 'declining season' (Wu et al. 2015). In Poland, the accumulating season usually starts in October-November and ends in FebruaryMarch, while the declining season usually 
occurs in April and lasts until September (Somorowska 2015). In particular years these seasons might be significantly shifted in time due to extreme meteorological conditions.

Soil moisture estimates can be derived from in situ measurements, satellite observations, or land surface modelling. In Poland, continuous in situ monitoring of surface soil moisture was launched in 2008 in the framework of Agricultural Drought Monitoring, currently comprising twenty ground stations. This network provides valuable point data, but it is insufficient in and of itself for large-scale hydrological investigation. Soil moisture data derived from Earth observation satellites are available from the H-SAF (EUMETSAT Satellite Application Facility on Support of Operational Hydrology and Water Management - H-SAF). This product accurately captures soil moisture dynamics for a wide range of climatic and land surface conditions (e.g. Alberger et al. 2012; Massari et al. 2015), although it has not been in use for long, as it started operations in January 2013. Given these limitations, the outputs from the land surface model simulations are nevertheless recognized as the only available data for obtaining estimates of SWS for multiyear analyses on a national scale.

The Global Land Data Assimilation System (GLDAS) is generating a series of land surface state products, including soil moisture estimates. The figures are simulated by four land surface models (Rodell et al. 2004; Rui 2011). Essential attributes of these data are regular time step (3-hour and 1-month), relatively high spatial resolution ( 0.25 degree), and availability in near real-time. Several previous studies have compared GLDAS simulations to in situ observations (e.g. Dorigo et al. 2013; Zawadzki \& Kędzior 2014), satellite observations (e.g. Liu et al. 2009), and other model outputs (e.g. Diodato et al. 2014), with satisfactory agreement to a certain extent.

In this study, GLDAS Noah model simulations of monthly soil moisture series are used for the examination of SWS over Poland in the years 2000-2015. The specific objectives were the following: (1) to provide a quantitative assessment of SWS in the upper soil layers, (2) to detect extreme stages of SWS in 2000-2015, (3) to track temporal depletion and recharge patterns of the extreme stages of SWS, and (4) to provide an insight into the effect of precipitation deficit or surplus on the soil moisture stage. The study provides insight into months of the most extreme soil moisture stages linked to the dynamics of precipitation recharging in the upper soil layers.

\section{Data and Methods}

The soil moisture data were acquired from the GES DISC (Goddard Earth Sciences Data and Information Services Center) at NASA, through the Earth Observing System Data and Information System (EARTHDATA) for the period from November 1999 to October 2015. The monthly GLDAS data in GRIB format were downloaded from online resources (http://hydro1.gesdisc.eosdis.nasa.gov/data/ s4pa/GLDAS_V1/). This data set contains a series of land surface parameters, including soil moisture estimates simulated by the Noah model in the Global Land Data Assimilation System (GLDAS). Each data file has global coverage, consists of 1440 columns and 600 rows, and is stored in a geographic coordinate system. Soil moisture is expressed as the amount of water (in mm of water depth) present in a depth of a particular soil layer, representing soil water storage (SWS). The SWS data used in this study have a 0.25 degree spatial resolution for the period from March 2000 to October 2015 (Rodell \& Beaudoing 2007a). Additionally, data with a 1 degree spatial resolution were acquired for the period from November 1999 to February 2000 (Rodell \& Beaudoing 2007b), to fill the data gap in the series in 0.25 degree resolution.

Monthly SWS data in GRIB format were displayed in the Xconv software (http://cms.ncas. ac.uk/documents/xconv/index.html) as single variables and converted into the NetCDF output format. For each month of the period from November 1999 to October 2015 three files were created, that is 'soilm1', 'soilm2' and 'soilm3' as they are originally named in the GLDAS Noah model. Data represent 
SWS expressed in $\mathrm{mm}$, in unevenly spaced soil layers with the following depth boundaries: 0 to $10 \mathrm{~cm}$ ('soilm1'), 10 to $40 \mathrm{~cm}$ ('soilm2'), and 40 to $100 \mathrm{~cm}$ ('soilm3'). Using the 'Make NetCDF Raster Layer' Tool in ArcGIS 10.2, raster layers with a global coverage were created. Data files in 1.0 degree resolution were resampled into a 0.25 degree resolution using the 'Resample tool.' Raster data files were projected from the WGS84 into the Polish Coordinate System, PUWG92, by using 'Project Raster Tool.' Then, using an analysis mask covering the territory of Poland, and the 'Extract by Mask' Tool, raster files of monthly SWS were created and processed further in ArcGIS. Further calculations were done using the 'Weighted sum' Tool. SWS for the soil depth of $50 \mathrm{~cm}$ for a subsequent month and subsequent year was calculated in $\mathrm{mm}$ according to the equation:

$$
\begin{gathered}
\text { SWS }_{50, m, n}=\text { soilm } 1_{m, n}+\text { soilm } 2_{m, n} \\
+0.1667 \times \text { soilm }_{m, n}
\end{gathered}
$$

where:

$S W S_{50, m, n}$ - SWS in mm for soil depth of $50 \mathrm{~cm}$ for a subsequent month $m$ and subsequent year $n$,

soilm $1_{m, n}$ - SWS in $\mathrm{mm}$ for soil depth of $0-10 \mathrm{~cm}$, soilm $2_{m, n}$ - SWS in mm for soil depth of $10-40 \mathrm{~cm}$, soilm $3_{m, n}$ - SWS in $\mathrm{mm}$ for the soil depth of $40-100 \mathrm{~cm}$,

0.1667 - factor allowing determination of one-sixth of the SWS for soil depth of $40-100 \mathrm{~cm}$.

Spatial patterns of monthly SWS were presented for selected dry and wet years both for the winter (between 1 November and 30 April) and summer (between 1 May and 31 October) halves of the hydrological years.

Following the equation (1), images (raster files) of multiyear monthly mean of SWS were derived from data for the hydrological years 2000-2015, following the equation:

$$
\overline{\operatorname{SWS}}_{50, m}=\frac{1}{16} \sum_{n=1}^{n=16} S W S_{50, m, n}
$$

where:

$\overline{S W S}_{50, \mathrm{~m}}$ - multiyear monthly mean of SWS in $\mathrm{mm}$ at soil depth of $50 \mathrm{~cm}$ for a month $\mathrm{m}$, $m$ - subsequent month of the year,

$n$ - subsequent year of the period 2000-2015.

Then images (raster files) of multiyear seasonal mean of the SWS were elaborated for four periods of the hydrological year as follows:

$$
\begin{aligned}
& \overline{S W S}_{50, \text { Nov-Jan }}= \\
& =\frac{1}{3}\left(\overline{S W S}_{50, \text { Nov }}+\overline{S W S}_{50, \text { Dec }}+\overline{S W S}_{50, \text { Jan }}\right) \\
& \overline{S W S}_{50, \text { Feb-Apr }}= \\
& =\frac{1}{3}\left(\overline{S W S}_{50, \text { Feb }}+\overline{S W S}_{50, \text { Mar }}+\overline{S W S}_{50, \text { Apr }}\right) \\
& \overline{S W S}_{50, \text { May }-J u l}= \\
& =\frac{1}{3}\left(\overline{S W S}_{50, \text { May }}+\overline{\operatorname{SWS}}_{50, \text { Jun }}+\overline{\text { SWS }}_{50, \text { Jul }}\right) \\
& \overline{S W S}_{50, \text { Aug-Oct }}= \\
& =\frac{1}{3}\left(\overline{S W S}_{50, \text { Aug }}+\overline{\operatorname{SWS}}_{50, \text { Sep }}+\overline{\operatorname{SWS}}_{50, \text { Oct }}\right)
\end{aligned}
$$

where:

$\overline{S W S}_{50, \text { Nov-Jan, }} \overline{S W S}_{50, \text { Feb-Apr, }} \overline{S W S}_{50, \text { May-Jul }}$ and $\overline{S W S}_{50, \text { Aug-Oct }}$

- multiyear seasonal mean of SWS in mm for soil depth of $50 \mathrm{~cm}$ for four periods lasting from November to January, February to April, May to July and August to October respectively.

Using these four seasonal patterns, SWS images for Poland were elaborated and characterized.

In order to detect extreme stages of SWS in the hydrological years 2000-2015 at the national scale, in a first step an average of all cells in raster files of the $S_{W} S_{50, m, n}$ was calculated using the 'Get Raster Properties - Mean' Tool and named as SWSA ${ }_{50, m, n}$. Then, to calculate the anomaly for a particular month, the multiyear mean of the particular month's average was subtracted from each $S W S A_{50, m, n}$ as the following:

$$
\begin{gathered}
\text { Anomaly }_{50, m, n}= \\
=\mathrm{SWSA}_{50, m, n}-\overline{\operatorname{SWSA}}_{50, m}
\end{gathered}
$$

where:

Anomaly $_{50, m, n}$ - monthly anomaly of the SWSA $A_{50, m, n}$ over Poland for the month $m$ of the year $n$, 


$$
\begin{aligned}
& \text { SWSA } A_{50, m, n} \text { - average of all cells in the raster } \\
& \text { files of } S W S_{50, m, n} \text { for the month } m \\
& \text { of the year } n \text { (the average monthly } \\
& \text { soil water storage over Poland), } \\
& \overline{S W S A}_{50, m} \text { - multiyear mean of the SWSA } A_{50, m, n} \\
& \text { for a month } m \text {. }
\end{aligned}
$$

Extremely dry and wet months were detected based on the highest positive and negative anomalies in SWS. Then propagation of soil wetness condition was examined for anomalous years, determining accumulating and declining seasons in the context of monthly precipitation.

Monthly precipitation data were acquired in NetCDF format from the Global Precipitation Climatology Center (GPCC) at 0.5 degree spatial resolution for the years 1999-2013 from online resources (ftp://ftp.dwd.de/pub/ data/gpcc/html/fulldata_v7_doi_download. html) and were supplemented by the GPCC monitoring data product (GPCC MP) for the years 2014-2015 from the following source: ftp://ftp.dwd.de/pub/data/gpcc/html/gpcc_ monitoring_v5_doi_download.html (Schneider et al. 2015a,b). The procedure of precipitation data processing in ArcGIS was similar to the one described above that concerned SWS maps. Using the 'Make NetCDF Raster Layer' tool from the 'Multidimension Tools' toolbox, raster layers from a netCDF precipitation variable were created for global coverage. Using a mask covering the territory of Poland, monthly precipitation maps were generated and the average monthly precipitation over Poland was determined for the hydrological years 2000-2015. Based on monthly values, the average annual precipitation over Poland for each hydrological year was estimated, and the multiannual mean precipitation was determined.

In order to provide an insight into the effects of precipitation deficit or surplus on the soil water storage stage, the correlation between the SWSA ${ }_{50, m, n}$ and antecedent precipitation was investigated for the months of the lowest soil water storage (July, August and September). Antecedent precipitation was calculated for different accumulation periods, here presented at different time scales, from one to twelve months. In effect, one-month precipitation represents conditions from a particular month, while 3-month precipitation represents accumulated antecedent precipitation for the 3-month period. The assessment of correlation between antecedent precipitation and the soil water storage was aimed to provide the answer to the question which precipitation time scale gives the highest correlation with the average monthly soil water storage over Poland.

\section{Results and Discussion}

Mean seasonal patterns of soil water storage vary significantly across the year (Fig. 1). High values of the SWS usually appear in the winter half of the hydrological year (Fig. 1A, $1 \mathrm{~B})$, when water is gradually accumulating. In effect, the mean values for the season from February to April are relatively higher (Fig. 1B). During the next seasons, in the summer half of the hydrological year, which comprises the months from May to July (Fig. 1C) and from August to October (Fig. 1D), a decline in the mean seasonal soil water storage is observed. Thereafter the seasonal soil water cycle is closed and starts from the beginning from November onward. Considering the average monthly soil water storage over Poland $S W S A_{50, m, n}$ recharge of the soil water storage usually appears in months from October until February (the accumulating season), whereas from March until September (the declining season) a depletion of soil water storage is observed (Fig. 2A).

In the examined period of 2000-2015, the driest conditions in the declining season were detected in August 2003, July 2006, March 2014 and September 2015 (Fig. 2A). In these months relatively high negative anomalies of soil water storage (as calculated by Equation 7) were detected, reaching even $-43 \mathrm{~mm}$ in September 2015 (Fig. 2B). It is worth noting that relatively dry conditions throughout the year 2015 were preceded by a drier than usual year 2014. Exceptionally high SWS appeared in May and June 2010 (Fig. 2A). In these months positive anomalies of SWS 

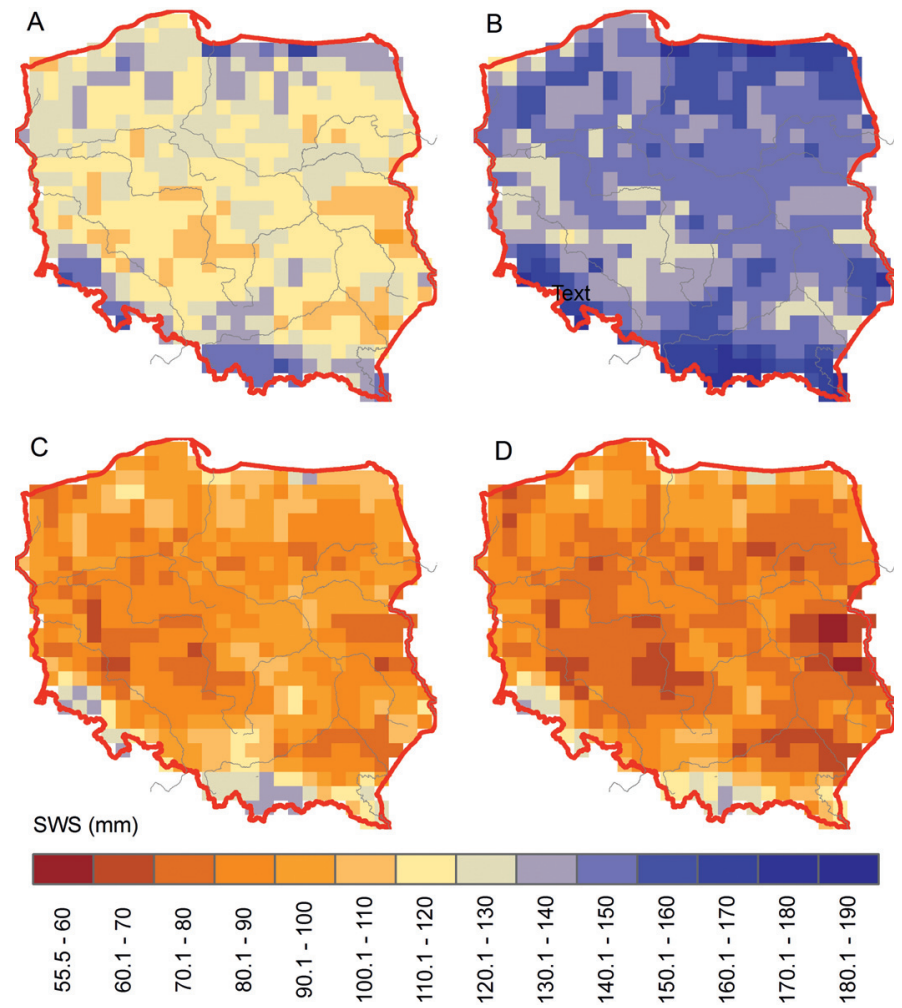

Figure 1. Spatial distribution of the multiyear seasonal mean of soil water storage in Poland in the 0-50 cm surface soil layer in the months: November - December - January (A), February - March April (B), May - June - July (C), and August - September - October (D). Multiyear seasonal means were calculated for the hydrological years 2000-2015 according to the equations 3, 4, 5 and 6, respectively
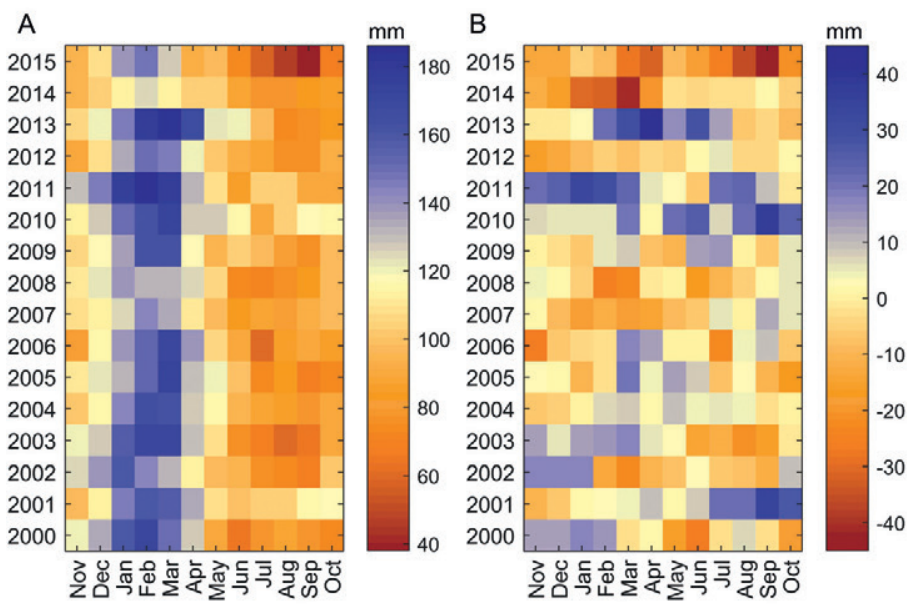

Figure 2. The average monthly soil water storage over Poland $\left(S W S A_{50, m, n}\right)$ in the soil layer of $50 \mathrm{~cm}$ depth (A), and monthly anomaly of soil water storage (Anomaly $y_{50, m, n}$ ) over Poland calculated according to Equation 7 (B). Values were calculated for the hydrological years 2000-2015 
reached approximately $22 \mathrm{~mm}$ and $25 \mathrm{~mm}$, respectively (Fig. 2B). A relatively wet summer was also observed in 2001, while in 2011 and 2013 higher than average SWS appeared in selected months of the winter half of the year, extending from November until April.

Annual curve of monthly $\overline{S W S A}_{50, m}$ evaluated for the years 2000-2015 shows a clear seasonal pattern, with the lowest values of the order of $80 \mathrm{~mm}$ occurring in July, August and September (Fig. 3). The curve for 2003 distinctly differs from the aforementioned one, with $S W S A_{50, m, n}$ well above-average figures in the months from November until May, and $S W S A_{50, m, n}$ well-below-average figures in the months June-July-August-September (Fig. 3A). The annual curve for 2006 differs significantly, with anomalies, both negative and positive, occurring throughout the entire year (Fig. 3B). In contrast, the year 2010 was extremely wet with exceeding multiyear means in all months,
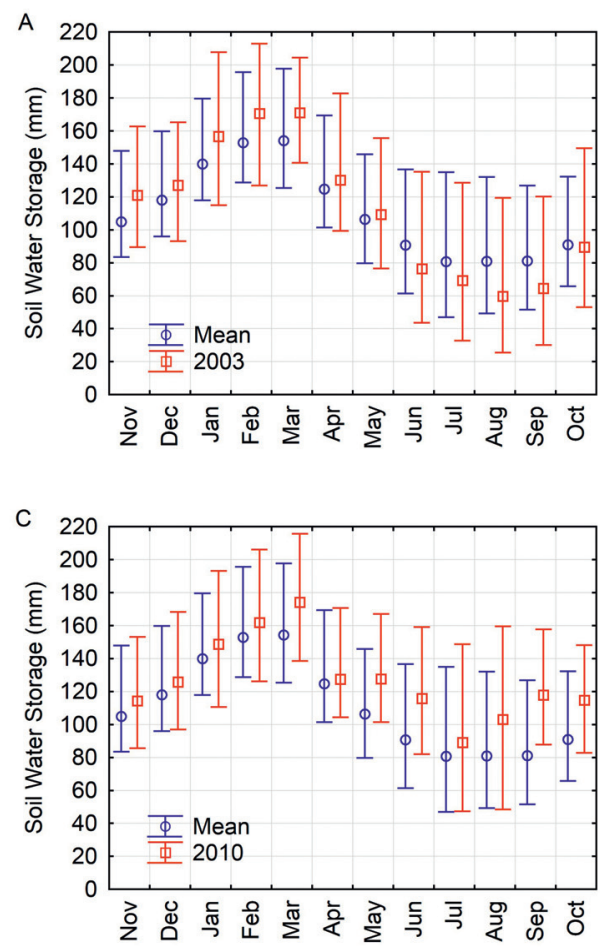

with significant positive anomalies in May and June (Fig. 3C). The year 2015, in turn, was extremely dry, with negative anomalies occurring throughout the entire year (Fig. 3D) and the highest soil water storage deficiency in the consecutive months of July, August, and September.

In order to assess how closely soil water storage responds to the amount of precipitation recharging the upper soil layers, annual patterns of monthly precipitation were assessed. The average annual precipitation (AAP) over Poland varied in the years 2000-2015 within a broad range, between $480 \mathrm{~mm}$ in 2015 and $758 \mathrm{~mm}$ in 2010 (Fig. 4A), respectively. The multiannual mean precipitation (MMP), estimated as an arithmetical mean from the AAP sums, equals $631 \mathrm{~mm}$. In years marked by extremely dry summer months, AAP equaled to $75 \%$ of MMP in $2003,97 \%$ in 2006 , and approximately $76 \%$ in 2015. Although in 2006 the AAP was close to the multiannual mean
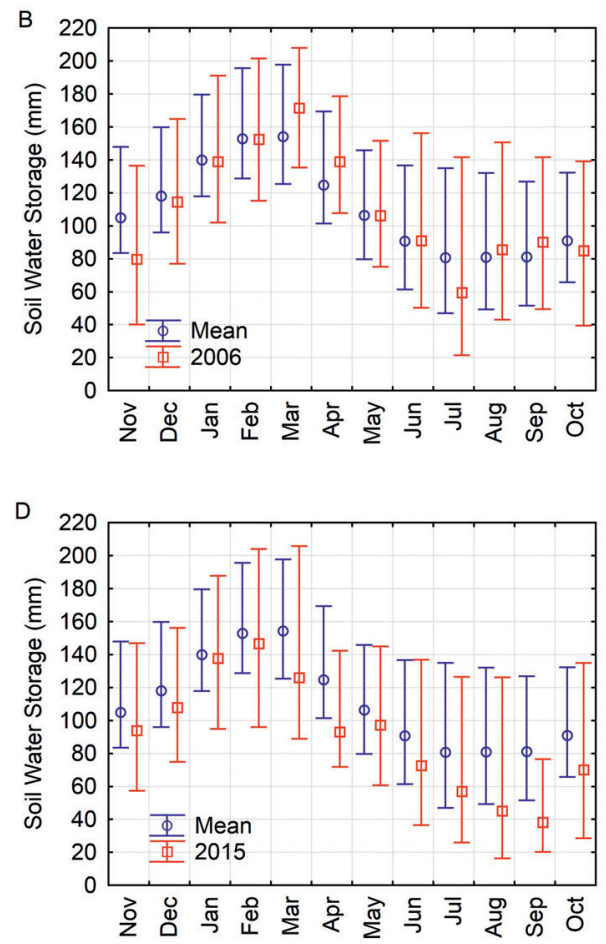

Figure 3. Average monthly soil water storage over Poland (SWSA $50, m, n)$ in 2003 (A), 2006 (B), 2010 (C), and 2015 (D) as compared to the multiyear monthly mean $\left(\overline{S W S A}_{50, m}\right)$ for years 2000-2015. Whiskers represent the maximum and minimum $\left(S W S A_{50, m, n}\right)$ values 
A

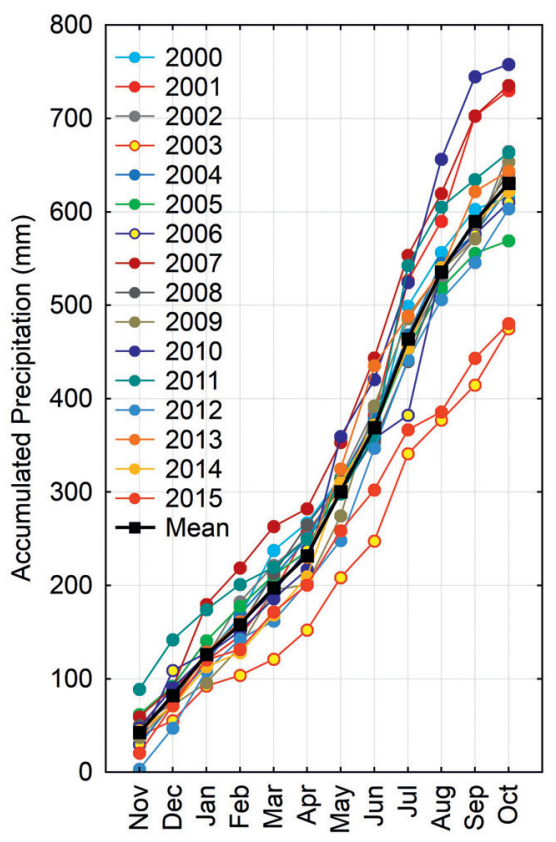

B

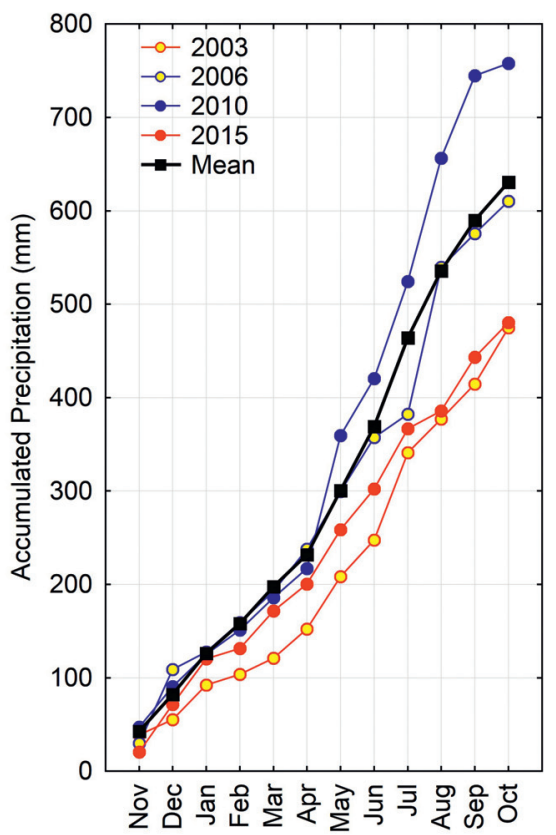

Figure 4. Accumulated averages of monthly precipitation over Poland in the hydrological years 2000-2015 (A), and in years marked by extremely dry summer months (2003, 2006 and 2015) and extremely wet summer months (2010), (B)

precipitation, it should be noted that preceding accumulated precipitation in the period November 2005-July 2006 was approximately $80 \mathrm{~mm}$ lower than the accumulated mean for these months, and in 2006 it was close to the respective values in 2003 and 2006 (Fig. 4b). Large intra-annual precipitation variability and relatively low seasonal precipitation (as compared to the multiyear mean) apparently led to less precipitation infiltrating the surface soil layers, resulting in dry soils and negative anomalies of SWS discussed above.

The effect of antecedent precipitation on the soil water storage stage in July, August and September is revealed by the correlation between the precipitation at different time scales and the SWSA $A_{50, m, n}$. The highest degree of correlation is found for 3-month antecedent precipitation (Tab. 1). Longer time scales of precipitation do not increase the correlation. Such seasonal response of soil water storage to antecedent precipitation was formerly highlighted by e.g. Spennemann et al. (2014), although their analysis was conducted for soil layers of different depths and for standardized values of precipitation. Here it is shown that 3-month antecedent precipitation might serve as a first proxy for determining the soil water storage stage in the summer, when the highest soil water deficits occur. However obviously,

Table 1. Correlation coefficients between SWSA and antecedent precipitation at different time scales

\begin{tabular}{|l|c|c|c|c|c|c|c|c|c|c|c|c|}
\hline $\begin{array}{l}\text { Time Scale } \\
\text { (Months) }\end{array}$ & 1 & 2 & 3 & 4 & 5 & 6 & 7 & 8 & 9 & 10 & 11 & 12 \\
\hline $\begin{array}{l}\text { Correlation } \\
\text { Coefficient }\end{array}$ & 0.48 & 0.78 & 0.91 & 0.84 & 0.81 & 0.82 & 0.82 & 0.80 & 0.79 & 0.81 & 0.75 & 0.79 \\
\hline
\end{tabular}


precipitation alone does not fully explain SWS variability. Another important factor is evapotranspiration directly influencing dynamics of water stored in surface soil layers, highly dependent on meteorological conditions, vegetation, and soil hydraulic properties.

Spatial patterns of monthly soil water storage over Poland for selected hydrological years are presented at figures 5 and 6 .
During all months of the winter half of the hydrological year 2003, SWS was slightly higher than the multiyear monthly mean values (Fig. 2, Fig. 5). From June onward, SWS decreased significantly, reaching extremely low values in August and September (Fig. 6). Anomalies (as calculated by Equation 7) for these months reached $-21 \mathrm{~mm}$, and $-16 \mathrm{~mm}$, respectively. They were caused by relatively
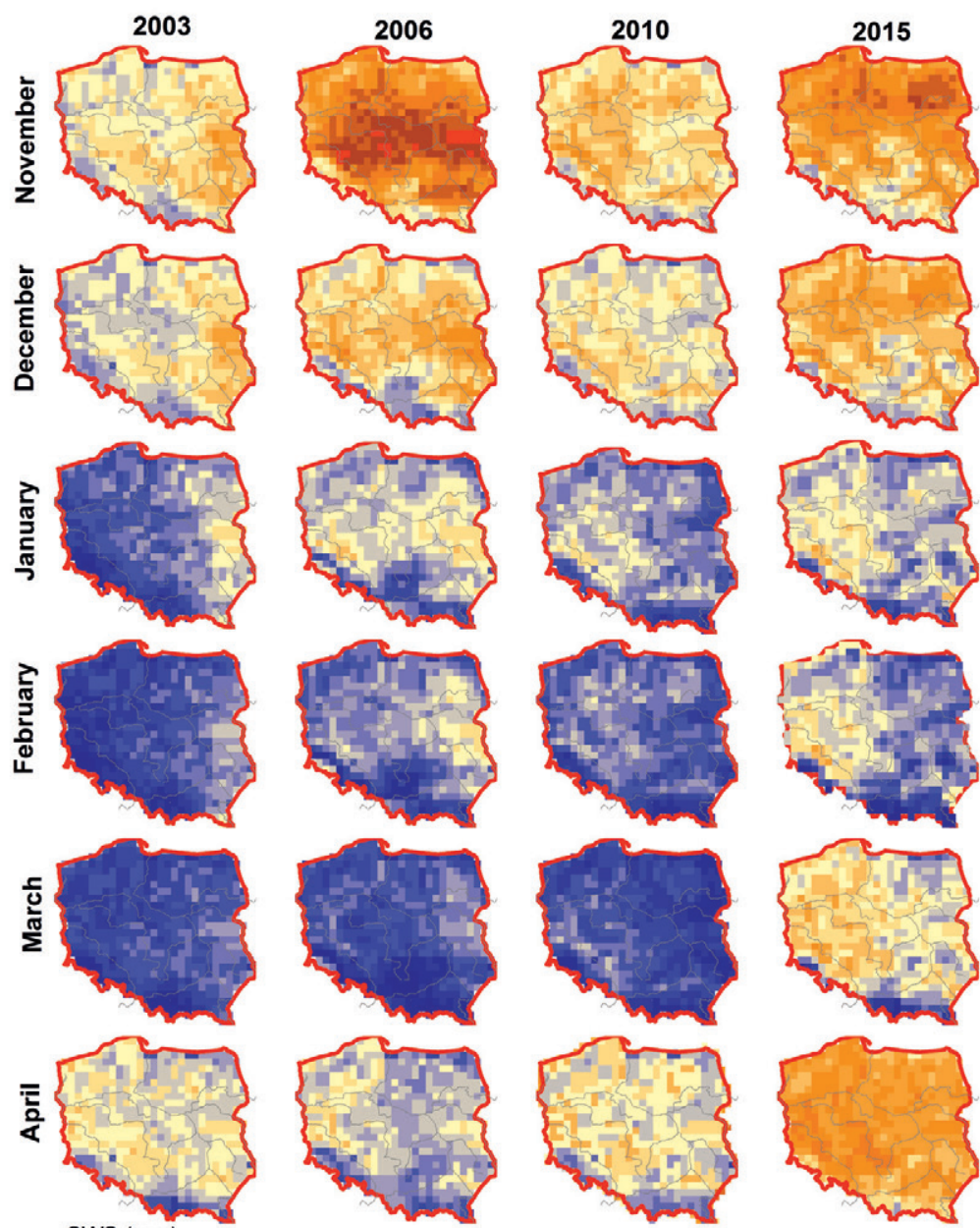

SWS (mm)

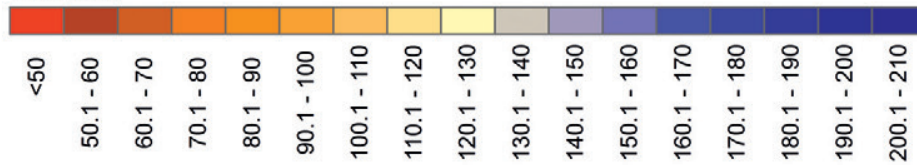

Figure 5. Spatial patterns of monthly soil water storage in Poland in the $0-50 \mathrm{~cm}$ surface soil layer in the winter half(November until April) of the hydrological years: 2003, 2006, 2010, and 2015 
low precipitation. From November 2002 to August 2003, the accumulated precipitation was much lower than the multiyear mean of about $160 \mathrm{~mm}$ (Fig. 4B). This resulted in a widespread low SWS across Poland in August and September (Fig. 5). The area with SWS lower than $50 \mathrm{~mm}$ constituted approximately $3 \%$ of the country in June, $18 \%$ in July, 31\% in August and $23 \%$ in September.
It is worth noting that $50 \mathrm{~mm}$ of soil water storage in the soil layer of $50 \mathrm{~cm}$ depth is the equivalent of $10 \%$ of volumetric soil moisture which, for mineral soils, corresponds to the critical soil water content of limited availability for plants. In effect the SWS below $50 \mathrm{~mm}$ should be considered as an amount characteristic for soil water deficiency indicating agricultural drought.
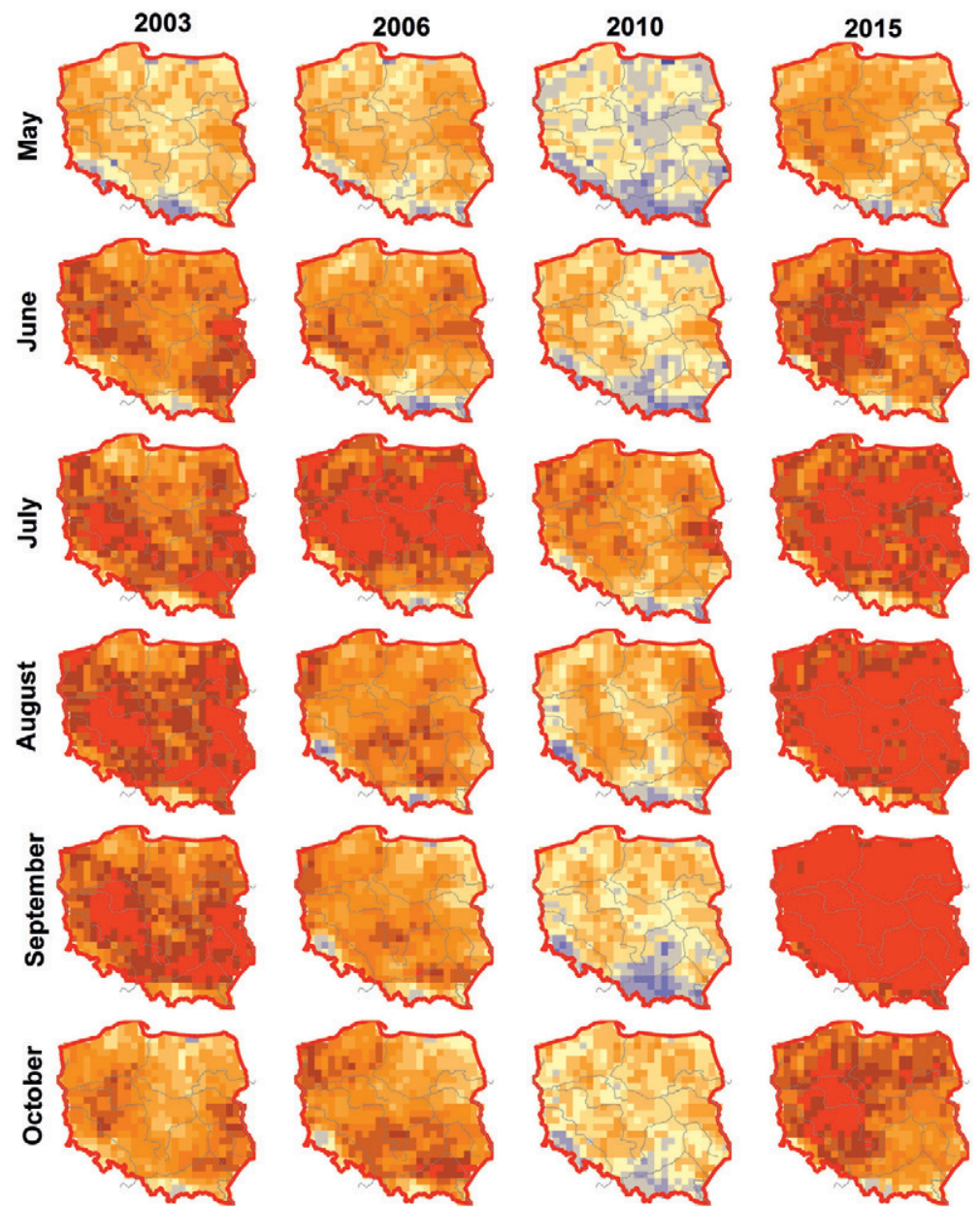

SWS (mm)

인

Figure 6. Spatial patterns of monthly soil water storage in Poland in the 0-50 cm surface soil layer in the summer half (May until October) of the hydrological years: 2003, 2006, 2010, and 2015 
Much different spatial patterns of SWS occurred in 2006. The highest negative anomaly $(-23 \mathrm{~mm})$ occurred in July with a widespread SWS lower than $50 \mathrm{~mm}$, covering 44\% of the national territory (Fig. 2, Fig. 6). It can be explained by relatively low precipitation in this month which accounted only for $26 \%$ of the multiyear monthly mean (Fig. 4b). However, as early as in August, due to extremely high precipitation of $157 \mathrm{~mm}$ (218\% of the multiyear monthly mean), the dryness was reduced. In the following months, in September and October, in most of country's territory SWS was close to the multiyear monthly mean.

Extremely wet conditions appeared throughout the entire 2010 hydrological year (Fig. 2, Fig. 5, Fig. 6). Precipitation well above the multiyear monthly mean occurred in May (206\%), June (88\%), August (183\%), and September (165\%). This caused high positive SWS anomalies in the respective months, of order of 22-37 mm. Response in soil water storage imposed by the high precipitation recharge was still present in the beginning of the hydrological year 2011 (Fig. 2).

Extremely dry conditions occurred throughout the entire hydrological year 2015 (Fig. 2, Fig. 5, Fig. 6). The annual precipitation was only $76 \%$ of the multiyear annual mean, while 3 -month precipitation in the months JulyAugust-September reached only $64 \%$ of the multiyear 3-month mean. Decreased precipitation recharge caused extremely low SWS (below $50 \mathrm{~mm}$ ) that affected $45 \%$ of the territory in July, 72\% in August, 94\% in September and $14 \%$ in October.

Overall, it is proven that soil water storage patterns vary significantly due to differences in seasonal and inter-annual precipitation, which impact soil water recharge. Symptoms of soil drought are the most prevalent in the summer half of the year, usually from July until September. However in particular years, due to long rainless periods, symptoms can extend over October and November (e.g. in the year 2005). Moreover, symptoms of drought also appear in the winter half of the year. This happened in the years 2008 and 2014 (from January to March). Relatively high soil water storage stages appear in the winter half of the year, usually in February or March. However high SWS also occur in summer half of the year. Such a situation happened in 2010 and 2013. In summary, it can be concluded that precipitation variability explains to a certain extent the variability in spatio-temporal patterns of the soil water storage. Other factors, like air temperature and duration of rainless periods analyzed on a daily basis, might provide additional insight into the temporal behavior of soil water storage under drought conditions.

\section{Conclusions}

In this paper, data acquired from GLDAS Noah simulations have been used to investigate the spatio-temporal variability of soil water storage over Poland in the years 2000-2015 and to gain knowledge regarding the precipitation conditions under which extreme SWS appear. Based on monthly spatial patterns of soil water storage, months in which dry and wet extremes appeared, were investigated. The following conclusions may be formulated:

1. Data acquired from GLDAS Noah simulations provide insight into the spatiotemporal patterns of soil water storage. The usefulness of the GLDAS data for mesoscale analysis has been shown. In further research the performance of GLDAS simulations might be checked against operational soil moisture products newly developed within EUMETSAT H-SAF, which are of comparable spatial resolution.

2. Soil water storage is usually recharged from October and November to February and depleted from March to September. This regularity is sometimes disturbed, depending on varying precipitation conditions. Unusually high precipitation recharge occurred in 2010 causing SWS excess throughout the entire hydrological year. High SWS in May 2010 was preceded by late snow thaw, which occurred in the second half of March. As a result, significantly high precipitation in May and June 2010 resulted in particularly high SWS. 
Contrasting low precipitation occurred in 2015, causing critical SWS of limited availability for plants and affecting $45 \%$ of the territory of Poland in July, $72 \%$ in August, and as much as 94\% in September. Relatively low SWS also appeared in August 2003 and July 2006.

3. The effect of antecedent precipitation on soil water storage stage in July, August and September was revealed by the correlation between the precipitation at different time scales and the average monthly soil water storage over Poland. The highest correlation was found for the 3-month antecedent precipitation. 3-month antecedent precipitation can serve as a first proxy for determining the soil water storage stage in July-August-September, when the highest soil water storage deficiencies occur.

\section{References}

Alberger C., De Rosnay P., Gruhier C., Muñoz-Sabater J., Hasenauer S., Isaksen L., Kerr Y., WAGNER W., 2012. Evaluation of remotely sensed and modelled soil moisture products using global ground-based in situ observations. Remote Sensing of Environment, vol. 118, no. 11, pp. 215-226.

Diodato N., Brocca L., Bellocchi G., Fiorillo F., Guadagno F.M., 2014. Complexity-reduction modelling for assessing the macro-scale patterns of historical soil moisture in the Euro-Mediterranean region. Hydrological Processes, vol. 28, no. 11, pp. 3752-3760.

Dorigo W.A., Xaver A., Vreugdenhil M., Gruber A., Hegyiová A., Sanchis-Dufau A.D., WAgneR W., DrusCh M., 2013. Global automated quality control of in situ soil moisture data from the International Soil Moisture Network. Vadose Zone Journal, vol. 12, no. 3, 1539-1663.

Jokiel P. (ed.), 2008. Zjawiska ekstremalne i zdarzenia nadzwyczajne w środkowej Polsce. Acta Universitats Lodziensis: Folia Geographica Physica, vol. 8, Łódź: Wydawnictwo Uniwersytetu Łódzkiego.

Kędziora A., Kępińska-Kasprzak M., Kowalczak P., Kundzewicz Z.W., Miler A.T., Pierzgalski E.,
4. This study provides an insight into extreme soil water storage at a country scale. More detailed local studies might require a distributed hydrological modelling approach in a dense spatial grid, using local meteorological and soil characteristics.

\section{Acknowledgements}

The GLDAS data used in this study were acquired as part of the mission of NASA's Earth Science Division and they were archived and distributed by the Goddard Earth Sciences (GES) Data and Information Services Center (DISC).

Editors' note:

Unless otherwise stated, the sources of tables and figures are the authors', on the basis of their own research.

TOKARCZYK T., 2014. Zagrożenia zwiqzane z niedoborem wody. Nauka, no. 1, pp. 149-172.

LiU Y.Y., McCabe M.F., Evans J.P., Van DiJK A.I.J.M., De Jeu R.A.M., SU H., 2009. Comparison of soil moisture in GLDAS model simulations and satellite observations over the Murray Darling Basin [in:] R.S. Anderssen, R.D. Braddock, L.T.H. Newham (eds.), Proceedings of the International Congress on Modelling and Simulation, Cairns, Australia, 13-17 July, pp. 2798-2804.

Massari C., Brocca l., Ciabatta L., Moramarco T., Gabellani S., Albergel C., De Rosnay P., Gabellani S., Wagner, W., 2015. The use of H-SAF soil moisture products for operational hydrology: Flood modelling over Italy. Hydrology, vol. 2, no. 1, pp. 2-22.

Rodell M., BeAudoing H.K., 2007a. GlDAS Noah Land Surface Model L4 Monthly $1.0 x$ 1.0 degree V001. NASA/GSFC/HSL, Greenbelt, Maryland, USA, Goddard Earth Sciences Data and Information Services Center (GES DISC), https://disc.sci.gsfc.nasa.gov/uui/datasets/ GLDAS_NOAH10_M_V001 [10 November 2016], DOI:10.5067/G6ON3ZR1EUIJ.

Rodell M., Beaudoing H.K., 2007b. GlDAS Noah Land Surface Model L4 Monthly $0.25 \times 0.25$ 
degree V001. NASA/GSFC/HSL, Greenbelt, Maryland, USA, Goddard Earth Sciences Data and Information Services Center (GES DISC), https://disc.sci.gsfc.nasa.gov/uui/datasets/ GLDAS_NOAH025_M_V001 [10 November 2016], DOI: 10.5067/7NP2052IA62C.

Rodell M., Houser P.R., Jambor U., Gottschalck J., Mitchell K., Meng C.-J., Arsenault K., Cosgrove B., Radakovich J., Bosilovich M.,. Entin J. K, Walker J.P., Lohmann D., Toll D., 2004. The global land data assimilation system. Bulletin of the American Meteorological Society, vol. 85, no. 3, pp. 381-394.

Romanowicz R.J., Nachlik E., Januchta-Szostak A., Starkel L., KundzeWicz Z.W., Byczkowski A., Kowalczak P., Żelaziński J., Radczuk L., Kowalik P., Szamakek K., 2014. Zagrożenia zwiqzane z nadmiarem wody. Nauka, no. 1, pp. 123-148.

RuI H., 2011. Read me document for Global Land Data Assimilation System V.1(GLDAS-1) Products. ftp://hydro1.sci.gsfc.nasa.gov/data/s4pa/ GLDAS_V1/README.GLDAS.pdf [10 November 2016].

Schneider U., Becker A., Finger P., Meyer-ChristOffer A., Rudolf B., Ziese M., 2015a. GPCC Full Data Reanalysis Version 7.0 at $0.5^{\circ}$ : Monthly Land-Surface Precipitation from Rain-Gauges built on GTS-based and Historic Data. DOI: 10.5676/DWD_GPCC/FD_M_V7_050.

Schneider U., Becker A., Finger P., Meyer-Christoffer A., Rudolf B., Ziese M., 2015b. GPCC Full
Data Reanalysis Version 7.0 at $1.0^{\circ}$ : Monthly Land-Surface Precipitation from Rain-Gauges built on GTS-based and Historic Data. DOI: 10.5676/DWD_GPCC/FD_M_V7_100.

SOMOROWSKA U., 2015. Detekcja glebowych zasobów wodnych w Polsce w latach 2000-2014 na podstawie mezoskalowych danych gridowych GLDAS [in:] D. Absalon, M. Matysik, M. Ruman (eds.), Nowoczesne metody i rozwiq̨zania w hydrologii i gospodarce wodnej. Monografie Komisji Hydrologicznej PTG, no. 3, Sosnowiec: Polskie Towarzystwo Geograficzne. Oddział Katowicki, pp. 337-350.

Spennemann P.C., Rivera J.A., Celeste Saulo A., Penalba O.C., 2015. A comparison of GLDAS soil moisture anomalies against standardized precipitation index and multisatellite estimations over South America. Journal of Hydrometeorology, vol. 16, no. 1, pp. 158-171.

Wu W.-Y., Lan C.-W., Lo M.-H., Reager J.T., FAMIGLIETTI J.S., 2015. Increases in the annual range of soil water storage at northern middle and high latitudes under global warming. Geophysical Research Letters, vol. 42, no. 10, pp. 3903-3910.

ZaWAdzkI J., KĘDZIOR M.A., 2014. Statistical analysis of soil moisture content changes in Central Europe using GLDAS database over three past decades. Central European Journal of Geosciences, vol. 6, no. 3, pp. 344-353.
(C) Urszula Somorowska

(C) Geographia Polonica

(C) Institute of Geography and Spatial Organization

Polish Academy of Sciences - Warsaw • 2017
Article first received • July 2015 Article accepted • December 2016 